\title{
ANALISIS PERBANDINGAN RISIKO (RISK) DAN TINGKAT PENGEMBALIAN (RETURN) ANTARA DEPOSITO DENGAN EMAS
}

\author{
Adilatus Salimah \\ Department of Management FEB UMM \\ E-mail: adilatussalimah@gmail.com
}

\begin{abstract}
The aim of this research is to compare the risk and returns on investment. The most preferred investment of Indonesian society is a low-risk investment. Investment instruments that include low-risk investments which is used in this research are an investment on deposit and investments on gold. Based on the results of the comparison and discussion in this research shows that investment on deposits is give more profit than investment on gold. Although the risk incurred in investment on deposit is higher than investment on gold by a margin of 0.0357 but the rate of return of investment on gold is higher than investment on deposit by a margin of $2.80 \%$. So, with different risk 0.0357 gives the rate of return $2.80 \%$ which mean is higher with $T$ Test shows significant point 0,010.
\end{abstract}

Keywords: risk, return, deposit, gold

\section{PENDAHULUAN}

Hal yang dipertimbangkan seorang investor dalam menanamkan modalnya, yaitu: 1) tingkat pengembalian yang diharapkan (expected return), 2) tingkat risiko (rate of risk), dan 3) ketersediaan dana yang akan diinvestasikan (Halim, 2003: 2). Tipe-tipe investor dalam berinvestasi terbagi tiga menurut Halim (2003: 38), yaitu : 1) investor menyukai risiko (risk seeker), 2) investor netral (risk neutrality) dan 3) investor yang tidak suka risiko (risk averter).

Kaslan Rian (2015: 17) mengatakan bahwa investasi emas merupakan jenis investasi yang digemari masyarakat Indonesia. Selain itu, produk perbankan yang berupa tabungan deposito juga digemari masyarakat Indonesia. Dilihat dari profilnya, masyarakat Indonesia memang masih tipe investor yang konservatif. Artinya, mereka masih ragu-ragu berinvestasi di produk yang berisiko tinggi.

Deposito termasuk investasi yang paling digemari di masyarakat Indonesia dikarenakan memiliki tingkat risiko yang rendah (low risk). Menurut Kasmir (2008: 84) deposito merupakan simpanan jenis ketiga yang diterbitkan oleh bank, jangka waktu deposito bervariasi mulai dari 1 , $2,3,6,12,18$, sampai dengan 24 bulan. Hal ini akan membantu masyarakat mengatur keuangan 
pribadi terutama untuk kebutuhan jangka panjang.

Selain deposito, emas juga termasuk investasi yang low risk atau memiliki tingkat risiko yang rendah. Harga emas dalam posisi yang stabil bahkan cenderung meningkat. Menginvestasikan penghasilan dengan membeli emas, baik emas perhiasan maupun emas batangan sering dilakukan masyarakat Indonesia. Berbeda dengan deposito, tingkat pengembalian (return) yang dihasilkan oleh investasi emas adalah capital gain (loss) dari investasi emas tersebut yang diperoleh dari selisih nilai jual dan nilai beli harga emas, dimana harga emas yang berfluktuasi dan cenderung mengalami kenaikan. Investasi emas cenderung stabil dan tidak terpengaruh inflasi (zero inflation).

Berdasarkan penjelasan tentang fenomena tersebut maka rumusan masalah penelitian yang akan diteliti pada penelitian ini antaralain: (1) Apakah terdapat perbedaan risiko (risk) antara deposito dengan emas?, (2) Apakah terdapat perbedaan tingkat pengembalian (return) investasi antara deposito dengan emas?, (3) Investasi manakah yang lebih menguntungan antara berinvestasi pada deposito dan berinvestasi pada emas?. Sehingga tujuan penelitian ini adalah untuk (1) untuk menganalisis atau mengkaji perbedaan risiko (risk) investasi antara deposito dengan emas, (2) untuk menganalisis atau mengkaji perbedaan tingkat pengembalian (return) investasi antara deposito dengan emas, serta (3) untuk mengetahui investasi yang lebih menguntungkan antara investasi pada deposito dengan investasi pada emas.

Penelitian ini dibatasi agar pembahasan dapat terfokuskan maka yang dimaksud deposito yang dipilih adalah deposito dengan jangka waktu 12 bulan, suku bunga yang dijadikan acuan sebagai tingkat pengembalian (return) deposito adalah suku bunga yang ditentukan oleh Bank Indonesia. Harga emas dalam penelitian ini mengikuti harga yang ditentukan oleh PT. Aneka Tambang, Tbk.

Berdasarkan uraian diatas diketahui bahwa emas dan deposito memiliki kesamaan yaitu investasi yang minim risiko atau low risk yang lebih disukai oleh masyarakat Indonesia. Deposito dan emas memiliki tingkat pengembalian (return) yang berbeda dimana tingkat pengembalian (return) deposito sudah ditentukan di awal dan bernilai tetap sehingga tidak ada fluktuasi sedangkan tingkat pengembalian (return) emas belum pasti dan berfluktuasi setiap saat. Penulis tertarik untuk melakukan penelitian dengan judul "Analisis Perbandingan Risiko (Risk) dan Tingkat Pengembalian (Return) Antara Deposito dengan Emas".

\section{TINJAUAN PUSTAKA}

Halim (2003: 2) berpendapat bahwa investasi pada hakikatnya merupakan penempatan jumlah dana yang digunakan saat ini dengan harapan memperoleh keuntungan di masa yang akan datang.

Investasi adalah penundaan konsumsi saat ini untuk digunakan di dalam produksi yang efisien selama 
periode waktu tertentu. Ada 2 tipe investasi yaitu: 1.) Investasi langsung yaitu membeli aktiva keuangan yang diperjualbelikan, dan 2.) Investasi tidak langsung dilakukan dengan membeli saham dari perusahaan investasi yang mempunyai portofolio aktiva keuangan dari perusahaan lain. (Jogiyanto, 2007:5)

Jenis-jenis deposito yang ada di Indonesia, antara lain: 1) deposito berjangka merupakan deposito yang diterbitkan menurut jangka waktu tertentu, 2) sertifikat deposito adalah deposito yang diterbitkan dengan jangka waktu 2, 3, 6, 12, dan 24 bulan, dan 3) deposito on call merupakan deposito yang berjangka waktu minimal tujuh hari dan paling lama kurang dari 1 bulan. (Kasmir, 2009: $85)$.

Risiko yang dihadapi ketika berinvestasi ditunjukkan oleh besar kecilnya penyimpangan tingkat imbal hasil yang diharapkan (expected rate of return) dengan tingkat imbal hasil yang dicapai secara riil (actual rate of return) (Halim, 2015: 157).

Jogiyanto (2007: 130) menyatakan bahwa risiko sering dihubungkan dengan penyimpangan dari outcome yang diterima dengan yang diekspektasi. Untuk menghitung risiko metode yang banyak digunakan adalah deviasi standar (standard deviation) yang mengukur absolut penyimpangan nilai-nilai yang sudah terjadi dengan nilai ekspektasinya.

Halim (2015: 39) mengatakan bahwa ada beberapa jenis risiko yang mungkin timbul dan perlu dipertimbangkan dalam membuat keputusan investasi, yaitu, risiko bisnis (business risk), risiko suku bunga (interest rate risk), risiko pasar (market risk), risiko daya beli (purchasing power risk).

Dalam pengukuran risiko (risk) aset tunggal, Metode yang digunakan dalam menghitung risiko adalah standar deviasi (standard deviation) yaitu mengukur absolut penyimpangan nilainiai yang sudah terjadi dengan nilai ekspektasinya (Jogiyanto, 2007: 131).

$$
\sigma=\sqrt{\frac{\sum_{i=1}^{n}\left[X_{i}-E\left(X_{i}\right)\right]^{2}}{n-1}}
$$

Dengan $\sigma$ adalah standar deviasi, $\mathrm{Xi}$ adalah nilai pada periode ke-i, $\mathrm{E}(\mathrm{X})$ adalah nilai ekspektasi, dan $\mathrm{N}$ adalah jumlah dari observasi.

Halim (2015: 256) menyatakan imbal hasil (return) merupakan keuntungan yang diperoleh dari investasi, dibedakan menjadi dua macam yaitu pertama, imbal hasil yang telah terjadi (actual return) berdasarkan pada data historis dan kedua, imbal hasil yang diharapkan (expected return) akan diperoleh investor pada masa mendatang.

Tingkat pengembalian (return) adalah hasil yang akan diperoleh dari investasi. Return dibagi menjadi dua macam yaitu return realisasi yang sudah terjadi dan return ekspektasi yang diharapkan diperoleh di masa yang datang. (Jogiyanto, 2007: 109).

Pengukuran Return Aset Tunggal,dilakukan dengan cara menghitung return aset tunggal menggunakan capital gain atau capital 
loss yaitu selisih harga investasi sekarang relatif dengan harga periode yang lalu, dapat menggunakan rumus berikut (Jogiyanto, 2007: 110):

$$
R t=\frac{P_{t}-P_{t-1}}{P_{t-1}}
$$

Dengan, Rt adalah return bulan ke-t, Pt adalah harga pada bulan ke-t, dan Pt-1 adalah harga sebelum bulan ke-t.

Berdasarkan pemaparan tersebut maka hipotesis yang diajukan dalam penelitian ini adalah terdapat perbedaan antara risiko (risk) investasi deposito dengan risiko (risk) investasi emas, terdapat perbedaan antara tingkat pengembalian deposito dan tingkat pengembalian emas, dan berinvestasi pada deposito lebih menguntungkan daripada berinvestasi pada emas.

\section{METODE PENELITIAN}

Penelitian ini adalah jenis penelitian deskriptif komparasi risiko (risk) dan tingkat pengembalian (return) antara investasi deposito dan emas. Jenis data yang digunakan dalam penelitian ini adalah data dokumenter dengan sumber data sekunder meliputi: (1) Data tingkat suku bunga deposito per bulan pada Bank Indonesia untuk tahun 2012 2016, sebagai acuan tingkat pengembalian deposito yang diperoleh dari Bank Indonesia. (2) Data harga emas per bulan selama tahun 2012 2016 yang diproduksi oleh PT. Aneka Tambang, Tbk. sebagai acuan tingkat pengembalian emas yang diperoleh dari PT. Aneka Tambang, Tbk.
Pengumpulan data yang dilakukan dengan mendownload catatan-catatan atau dokumen-dokumen yang berkaitan dengan penelitian, dalam hal ini data-data yang diterbitkan secara online oleh Bank Indonesia dan PT. Aneka Tambang, Tbk.

Data yang diperoleh dalam penelitian ini akan dianalisis melalui beberapa tahap antaralain:

Mengubah data tingkat pengembalian (return) deposito per bulan menjadi tingkat pengembalian (return) rata-rata deposito per tahun. (2) Menghitung tingkat pengembalian (return) rata-rata deposito selama 5 tahun. (3) Menghitung tingkat pengembalian (return) emas per tahun. (4) Menghitung tingkat pengembalian (return) rata-rata emas selama 5 tahun. (5) Menghitung risiko (risk) deposito. Menghitung risiko (risk) emas. Membandingkan risiko (risk) investasi deposito dengan investasi emas. (6) Membandingkan tingkat pengembalian (return) investasi deposito dengan investasi emas. (7) Menganalisis investasi yang lebih menguntungkan antara berinvestasi pada deposito atau berinvetasi pada emas

Definisi operasional variabel dalam penelitian ini adalah sebagai berikut, risiko deposito adalah penyimpangan antara keuntungan diharapkan dengan keuntungan atas pengorbanan dana yang diinvestasikan. Risiko emas adalah penyimpangan antara keuntungan diharapkan dengan keuntungan atas pengorbanan aktiva yang diinvestasikan. Tingkat pengembalian deposito yaitu total keuntungan ataupun kerugian yang 
dialami oleh nasabah dalam satu periode tertentu yang dinyatakan sebagai suatu tarif persentase. Tingkat pengembalian emas adalah total keuntungan ataupun kerugian yang dialami oleh investor atau pemilik emas yang dihasilkan atas selisih harga beli emas dengan harga jual emas.

Pengujian hipotesis yang pertama dilakukan adalah menguji perbedaan antara risiko (risk) investasi deposito dengan emas dengan menggunakan rumus standar deviasi. Uji-t dua sampel independen (Independent Sampel t-Test) digunakan dalam penelitian untuk membandingkan selisih dua rata - rata (mean) dari dua sampel independen dengan asumsi data terdistribusi normal. Uji menggunakan tingkat signifikansi 5\% dalam hal ini berarti bahwa mengambil risiko salah dalam pengambilan keputusan untuk menolak hipotesis maksimal $5 \%$.

\section{HASIL PENELITIAN DAN PEMBAHASAN}

Tabel 1. Tingkat Pengembalian (Return) Deposito

\begin{tabular}{ccc}
\hline No. & Tahun & $\begin{array}{c}\text { Tingkat } \\
\text { Pengembalian }\end{array}$ \\
\hline 1. & 2012 & $6,54 \%$ \\
2. & 2013 & $5,75 \%$ \\
3. & 2014 & $7,55 \%$ \\
4. & 2015 & $7,52 \%$ \\
5. & 2016 & $6,63 \%$ \\
\hline
\end{tabular}

Dari Tabel 1. diketahui bahwa tingkat pengembalian (return) deposito tertinggi adalah pada tahun 2014 mencapai $7,55 \%$ per tahun. Sedangkan pada tahun 2013 merupakan tahun dimana tingkat pengembalian (return) deposito terendah yaitu sebesar 5,75\% per tahun.

Rata-rata tingkat pengembalian (return) deposito selama tahun 2012 sampai tahun 2015 adalah sebesar 6,80 $\%$. Hal ini menunjukkan makna bahwa setiap 1 rupiah akan mendapatkan keuntungan di masa depan sebesar $6,80 \%$ atau 0,0680. Artinya, ketika berinvestasi 1 rupiah dalam jangka waktu 1 tahun akan berubah menjadi Rp 1,0680. Deposito memiliki saldo minimal Rp 10.000.000,00 dan dalam jangka waktu 1 tahun kemudian akan menjadi Rp 10.680.000,00.

Tabel 2. Tingkat Pengembalian

\begin{tabular}{ccc} 
& \multicolumn{2}{c}{$($ Return $)$ Emas } \\
\hline No. & Tahun & $\begin{array}{c}\text { Tingkat } \\
\text { Pengembalian } \\
(\text { Return })\end{array}$ \\
\hline 1. & 2012 & $13 \%$ \\
2. & 2013 & $-5 \%$ \\
3. & 2014 & $-2 \%$ \\
4. & 2015 & $5 \%$ \\
5. & 2016 & $7 \%$ \\
\hline
\end{tabular}

Dari Tabel 2. di atas diketahui bahwa tingkat pengembalian (return) emas tertinggi adalah pada tahun 2012 mencapai $13 \%$ per tahun. Pada tahun selanjutnya emas terus mengalami penurunan dimana harga emas pada tahun tersebut mengalami penurunan yang cukup signifikan, namun pada tahun 2015 tingkat pengembalian emas sudah mulai membaik sampai tahun 2016.

Rata-rata tingkat pengembalian (return) deposito selama tahun 2012 sampai tahun 2015 adalah sebesar $4 \%$. Artinya, ketika berinvestasi 1 rupiah dalam jangka waktu 1 tahun akan 
berubah menjadi Rp 1,04. Misal harga emas dianggap Rp 400.000,00 per gram. Emas Batangan memiliki berat 5 gram, jadi investasi yang dikeluarkan adalah Rp 2.000.000,00 dan dalam jangka waktu 1 tahun kemudian akan menjadi Rp2.080.000 dari Rp 2.000 .000 dikali $4 \%$.

Hasil penelitian ini diperoleh standar deviasi selama periode penelitian tahun 2012 sampai 2016 sebesar 0,7549 yang menunjukkan bahwa risiko (risk) yang dihadapi oleh investor dalam berinvestasi pada deposito adalah 0,7549. Semakin kecil nilai penyimpangan maka semakin kecil risiko yang dihadapi oleh investor, begitu pula sebaliknya. Selisih antara tingkat pengembalian (return) yang telah terjadi dengan tingkat pengembalian rata-rata deposito sebesar 0,7549. Selisih atau penyimpangan ini sangat kecil sehingga risiko yang dihadapi investor juga sangat kecil.

Hasil penelitian ini diperoleh standar deviasi selama periode penelitian tahun 2012 sampai 2016 sebesar 0,7192 yang menunjukkan bahwa risiko (risk) yang dihadapi oleh investor dalam berinvestasi pada emas adalah 0,7192. Selisih antara return yang telah terjadi dengan return ratarata emas sebesar 0,7549. Selisih atau penyimpangan ini sangat kecil sehingga risiko yang dihadapi investor juga sangat kecil.
Tabel 3. Perbandingan Risiko (Risk) Antara Deposito dengan Emas

\begin{tabular}{lc}
\hline $\begin{array}{c}\text { Instrumen } \\
\text { Investasi }\end{array}$ & $\begin{array}{c}\text { Risiko } \\
\text { (Risk) }\end{array}$ \\
\hline Deposito & 0,7549 \\
Emas & 0,7192 \\
Selisih & 0,0357 \\
\hline
\end{tabular}

Dari Tabel 3. di atas diketahui bahwa perbandingan risiko antara deposito dan emas, nilai risiko deposito lebih besar dibandingkan dengan emas. Risiko emas lebih kecil dibandingkan dengan deposito. Akan tetapi selisih atau perbedaan antara risiko deposito dengan emas hanya berselisih kecil yaitu sebesar 0,0357. Jadi, risiko yang ditanggung investor deposito maupun emas hampir sama.

Tabel 4. Perbandingan Tingkat

Pengembalian (Return) Rata-Rata Investasi antara Deposito dengan Emas

\begin{tabular}{cc}
\hline $\begin{array}{c}\text { Instrumen } \\
\text { Investasi }\end{array}$ & $\begin{array}{c}\text { Tingkat } \\
\text { Pengembalian } \\
\text { (Return) }\end{array}$ \\
\hline Deposito & $6,80 \%$ \\
Emas & $4,00 \%$ \\
Selisih & $2,80 \%$ \\
\hline
\end{tabular}

Dari Tabel 4. di atas diketahui bahwa perbandingan tingkat pengembalian (return) rata-rata antara deposito dengan emas, nilai tingkat pengembalian (return) deposito lebih besar dibandingkan dengan emas, artinya tingkat pengembalian yang diperoleh oleh investor deposito lebih 
tinggi dibandingkan dengan tingkat pengembalian yang diperoleh investor emas. Nilai tingkat pengembalian (return) emas lebih kecil dibanding dengan tingkat pengembalian (return) deposito, artinya tingkat pengembalian (return) emas yang diperoleh oleh investor emas lebih rendah dibanding dengan tingkat pengembalian (return) investor emas.

Hasil uji beda pada program spss yang terdapat pada lampiran 7 menunjukkan tingkat signifikansi untuk uji F yaitu 0,010 kurang dari 5\% memiliki makna bahwa hasil penelitian tersebut signifikan. Hal yang sama juga pada uji t yang menunjukkan hasil 0,000 yang menunjukkan arti sangat signifikan.

Tabel 5. Perbandingan Risk dan

Return Antara Investasi Deposito dengan Emas

\begin{tabular}{lcc}
\hline \multicolumn{1}{c}{ Ket } & $\begin{array}{c}\text { Risiko } \\
(\text { Risk })\end{array}$ & $\begin{array}{c}\text { Tingkat } \\
\text { Pengembalian } \\
(\text { Return })\end{array}$ \\
\hline Deposito & 0,7549 & $6,80 \%$ \\
Emas & 0,7192 & $4,00 \%$ \\
Selisih & 0,0357 & $2,80 \%$ \\
\hline
\end{tabular}

Dari Tabel 5. di atas diketahui investasi deposito memiliki risiko (risk) sebesar 0,7549 memberikan tingkat pengembalian (return) sebesar $6,80 \%$. Berbeda dengan investasi emas yang memiliki risiko (risk) sebesar 0,7192 memberikan return sebesar 4,00 \%. Dari tabel tersebut kita dapat mengetahui bahwa dengan selisih risiko (risk) antara deposito dengan emas sebesar 0,0357 sedangkan selisih tingkat pengembalian (return) antara deposito dengan emas sebesar 2,80\%.

Maka kita dapat menyimpulkan investasi yang optimal adalah investasi pada deposito karena dengan risiko (risk) yang lebih tinggi sedikit hanya berselisih 0,0357 daripada emas, memberikan tingkat pengembalian (return) yang jauh lebih tinggi daripada emas yaitu berselisih 2,80\%.

\section{SIMPULAN}

Hasil dari analisis data yang telah dilakukan sebelumnya, maka diketahui bahwa terdapat perbedaan antara risiko (risk) investasi deposito dengan emas. Risiko (risk) investasi lebih tinggi daripada risiko (risk) investasi emas. Selain itu, juga terdapat perbedaan antara tingkat pengembalian (return) investasi deposito dengan tingkat pengembalian investasi emas. Tingkat pengembalian (return) investasi deposito lebih tinggi daripada tingkat pengembalian (return) investasi emas.

Perbandingan risiko (risk) dan tingkat pengembalian antara deposito dengan emas diketahui bahwa berinvestasi pada deposito lebih menguntungkan dikarenakan meskipun risiko (risk) yang ditanggung dalam berinvestasi pada deposito lebih tinggi daripada berinvestasi emas akan tetapi tingkat pengembalian (return) yang diberikan dalam berinvestasi emas lebih tinggi daripada berinvestasi pada deposito.

Hasil penelitian ini menunjukkan bahwa berinvestasi pada deposito lebih menguntungkan dibandingkan dengan berinvestasi pada emas, akan tetapi 
tidak menutup kemungkinan hasil penelitian lain dengan tahun berbeda menunjukkan bahwa berinvestasi pada emas lebih menguntungkan dibandingkan dengan berinvestasi pada deposito.

Dari penelitian ini saran yang dapat disampaikan penulis adalah sebagai berikut :Bagi manajemen perusahaan ataupun perbankan agar memperhatikan risiko (risk) yang ditanggung oleh investor maupun calon investor dan memberikan tingkat pengembalian (return) yang sesuai dengan risiko (risk) yang ditanggung. Bagi investor dan calon investor, dalam menginvestasikan dananya lebih baik memilih berinvestasi pada deposito untuk tahun 2012 sampai dengan 2016.

\section{DAFTAR PUSTAKA}

Adhitya Indra Gunawan dan Ni Gusti Putu Wirawati. 2012. Volume 4, Nomor 2. ISSN: 2302-8556. Perbandingan Berinvestasi Antara Logam Mulia Emas Dengan Saham Perusahaan Pertambangan Emas. E-Jurnal Akuntansi, Universitas Udayana. Arikunto, Suharsimi. 2013. Prosedur Penelitian (Suatu Pendekatan Praktik). Jakarta: Rineka Cipta.

Bank Indonesia, Pusat Informasi Pasar Uang.

http://pusatdata.kontan.co.id diakses pada tanggal 3 Desember 2016.

Daftar Bank di Indonesia. http://www.jurnalterbaik.com/20 13/01/daftar-nama-bank-bankdi-indonesia.html diakses pada tanggal 19 Januari 2017.
Daftar perusahaan tambang emas di Indonesia. http://www.sahamok.com/emiten /sektor-pertambangan/subsektor-pertambangan-logammineral-lainnyal diakses pada tanggal 19 Januari 2017.

Gambaran umum Bank Indonesia. http://www.bi.go.id/id/tentangbi/fungsibi/status/Contents/Default.aspx diakses tanggal 19 Januari 2017.

Gambaran umum PT. Aneka Tambang, Tbk. http://www.antam.com/index.php ?option=com_content $\&$ task $=v i e$ $w \& i d=32 \&$ Itemid $=2$ \&lang $=i d$ diakses tanggal 20 Januari 2017.

Grafik perkembangan harga emas untuk 5 tahun terakhir. http://harga-emas.org diakses pada tanggal3 Desember 2016.

Halim, Abdul. 2003. Analisis Investasi. Jakarta: Salemba Empat.

Halim, Abdul. 2015. Analisis Investasi dan Aplikasinya, dalam Aset Keuangan dan Aset Riil. Jakarta: Salemba Empat.

Jogiyanto. 2007. Teori Portofolio dan Analisis Investasi Edisi 2007. Yogyakarta: BPFE.

Kaslan, Rian. 2015. Indonesia: Tipe Investor Konservatif. Jakarta: Commonwealth.

Kasmir. 2009. Bank dan Lembaga Keuangan Lainnya. Edisi Revisi. Jakarta: PT RajaGrafindo Persada.

Lupita Putri and Subiakto Soekarno. 2012. Volume 1, Nomor 3. The Analysis Of Risk And Return Comparation Between Silver, 
Gold, JKSE, And Property In Pasar Kemis, Sukamantri, Kutajaya, Gelam Jaya And Kutabaru Wards In Kabupaten Tangerang For Long Term Investment. Bandung: Journal Of Business And Management.

Negara Produsen Terbesar Emas. http://www.indonesiainvestments.com/id/bisnis/komod itas/emas/item167? diakses tanggal 24 April 2017

Niko Silitonga dan Adler Haymans Manurung. 2008. Tingkat Pengembalian (Return) Berbagai Instrumen Investasi. Jakarta: IKPA Perbanas.

Ratu Sitti Bashiira Soelaiman and
Achmad Herlanto Anggono. 2012. Volume 1, Nomor 5. Risk And Return Comparison Analysis Among Gold, JKSE, And Property In Sumur Bandung, Bandung Wetan, And Coblong District In Long Term Investment. Bandung: Journal of Business And Management.

Syaparuddin. 2014. Volume 49, Nomor 1. Studi Komparasi Perhitungan Return Deposito Syari'ah di BSM dengan Deposito Konvensional di Bank Mandiri. Asy-Syir'ah Jurnal Ilmu Syari'ah dan Hukum. Sekolah Tinggi Agama Islam Negeri (STAIN) Watampone. 